原著

\title{
外来で血小板輸血を長期間継続する血液疾患患者の増加
}

一千葉県がんセンターにおける過去 5 年間の臨床疫学的検討一

\author{
酒井 力 ${ }^{122}$ 石井 昭広 ${ }^{2)}$ 佐藤 美智1) \\ 伊藤 道子 ${ }^{1)}$ 稲田 豊 ${ }^{1)}$ \\ 1)千葉県がんセンター輸血療法科 \\ ${ }^{2}$ 同 腫瘍・血液内科
}

(平成 15 年 2 月 4 日受付)

(平成 15 年 5 月 12 日受理)

\section{INCREASE IN THE NUMBER OF PATIENTS WITH HEMATOLOGICAL DISEASE RECEIVING LONG-TERM PLATELET TRANSFUSION AT AN OUTPATIENT CLINIC}

\author{
Chikara Sakai ${ }^{12)}$, Akihiro Ishii ${ }^{2)}$, Michi Sato ${ }^{1)}$, Michiko Ito $^{1)}$ and Yutaka Inada ${ }^{1)}$ \\ ${ }^{1)}$ Division of Blood Transfusion, Chiba Cancer Center Hospital \\ ${ }^{2)}$ Division of Hematology and Oncology, Chiba Cancer Center Hospital
}

To clarify the reason for a recent increase in platelet transfusion (PT) at the outpatient clinic (OC) of our hospital, a clinico-epidemiological study was performed. The total number of administrations of platelet concentrate (PC) used per year at the OC grew from 650 units (1998) to 2,220 units (2001). The number of patients receiving PT itself did not increase significantly, but the number of PT and of patients receiving PT repeatedly increased greatly. During the last 5 years, to prevent serious hemorrhage, nine patients ( 5 with acute myeloid leukemia and 4 with myelodysplastic syndrome) received 220 to 790 (mean 419) units of $\mathrm{PC}$ repeatedly during a period of 9 to 23 (mean 15) months. According to the degree of bleeding tendency, these patients received PT at intervals of one to four weeks. Two of nine patients stopped requiring PT and have survived, while the remaining seven patients died. Only one patient suffered from fatal bleeding (cerebral hemorrhage). Even the seven patients who eventually died were able to live at home managing their condition with good quality of life. These findings indicate that PT at the OC is important and beneficial for thrombocytopenic patients with hematological disease, and should be promoted more actively and efficiently.

Key words : Long-term platelet transfusion, Outpatient clinic, Hematological disease

はじめに

最近の医療の進歩は目覚しく，自己末梢血幹細 胞移植を用いた超大量化学療法や同種造血幹細胞 移植が日本中で日常的に行われるようになった。 これらの治療を可能にした要因の一つに血小板輸 血の進歩がある．昔から血小板輸血を必要とする 患者の大多数は白血病や再生不良性貧血などの血
液疾患患者であり ${ }^{122)}$ ，今もこの状況は本質的には 変わっていない．ただ従来の血小板輸血は専ら入 院患者が対象であったが最近われわれの病院では 外来における血小板輸血が非常に増えた。本稿は 当院の外来血小板輸血の増加の実態を調査し，そ の背景と臨床的意義を明らかにするものである. 


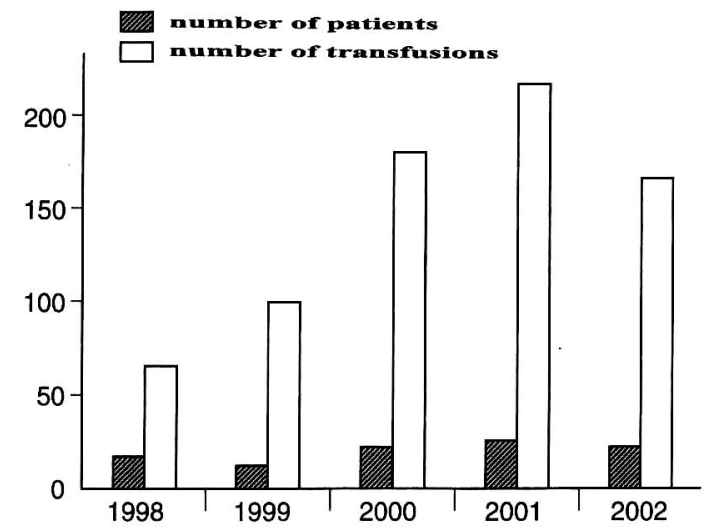

Fig. 1 The number of platelet transfusion per year at an outpatient clinic of Chiba Cancer Center Hospital from 1998 to 2002 .

\section{方法と対象}

外来血小板輸血は，原則として患者の受診日に 次回受診日の PC (platelet concentrate) 10 単位を 血液センターに注文し，受診日の前日に血液セン ターから供給してもらい輸血療法科で保管し, 翌 日の午前中に患者に輸血するようにした。

今回検討する患者の大部分は造血障害のために 血小板数の自然回復が期待できず，脳・肺・消化 管への出血を予防するために継続的な血小板輸血 が行われた. 輸血間隔を決める基準は血小板数よ り臨床所見（皮下出血や粘膜出血の有無）を重 視し, 出血傾向がある場合は 1 週間隔, 無い場合 は 2〜4 週間隔とした。

千葉県がんセンター輸血療法科に保管されてい る輸血記録より，1998 年 1 月〜2002 年 12 月の 5 年間に外来において施行された全ての血小板輸血 の患者名と輸血単位数を調べた.

更に 6 カ月以上継続して血小板輸血を続けた患 者（長期継続例）の臨床所見を検討した。

\section{結果}

年度別の外来血小板輸血の総単位数とその全血 小板輸血に占める割合は, 1998 年が 650 単位 $(8.0 \%), 1999$ 年が 995 単位 $(9.1 \%), 2000$ 年が 1,890 単位. (14.5\%), 2001 年が 2,220 単位 (17.0\%), 2002 年が 1,710 単位 (14.2\%) であった. 年度別の 外来血小板輸血の患者数と輸血回数を Fig. 1 に示

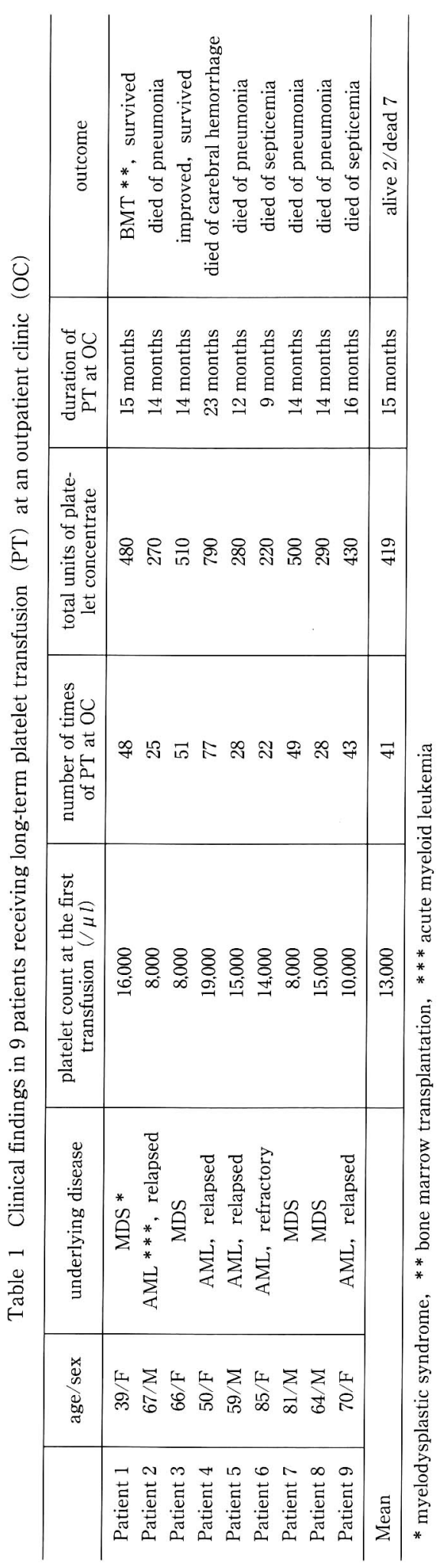


す. 患者数は 1999 年の 11 例が最少, 2001 年の 26 例が最多で, 輸血回数は最少が 1998 年の 65 件, 最多が 2001 年の 217 件であった.この 5 年間に年 間 100 単位以上の $\mathrm{PC}$ を輸血した症例は 18 例あ り，その基礎疾患は急性骨髄性白血病 (AML) 12 例，骨髄異形成症候群（MDS）6例であった.

6 力月以上に亘って外来血小板輸血を続けた長 期継続例は 9 例で，その臨床所見を Table 1 に示 す. AML の 5 例と MDS の 4 例で, 外来で最初に 血小板を輸血した時の血小板数は 8,000〜19,000/ $\mu l$ (平均 $13,000 / \mu l$ ) であった. 各症例の全輸血回 数は 22〜77 回（平均 41 回）, 総輸血単位数は 220〜790 単位 (平均 419 単位) で，その継続期間 は 9〜23 カ月（平均 15 力月）であった. 長期継続 例は，1998～1999 年は 2 例（Case 1,2）であった が 2000 年に 6 例（Case 2〜7）に，2001 年には 7 例（Case 3〜9）に増えた（Fig. 2）。これらの症例 の基礎疾患は活動性が低く外来で経口の抗癌剤は 投与されたが点滴静注による強い化学療法は施行 されていなかった９例の転帰は 2 例（Case 1 と Case 3) が生存中で, 7 例は Table 1 に示す原因で 死亡した. Case 1 は非血縁者間骨䯣移植が成功 し, Case 3 は MDS が改善し輸血なしで生存中で ある. Fig. 3 にその Case 3 と最終的に脳出血で死 亡した Case 4 の外来血小板輸血の実際を示す.
Case 3 は 2000 年 5 月に歯肉出血が止まらず 2 日 連続で PC10 単位を輸血したが 10 回目の輸血前 $4,000 / \mu l$ だった血小板数は翌日（11 回目の輸血 前) $47,000 / \mu l$ に増加し歯肉出血は止まった．本例 は 51 回目の血小板輸血を最後に輸血が不要に なった. Case 4 は初期には輸血間隔が 2 週で もほとんど出血傾向は無かったが次第に紫斑や歯 肉出血が出没するようになり，長期に亘り 1 週間 隔で輸血が続けられた。そして 2002 年 3 月に 77 回目の血小板輸血を受けた後に突然脳出血を起こ して死亡した.

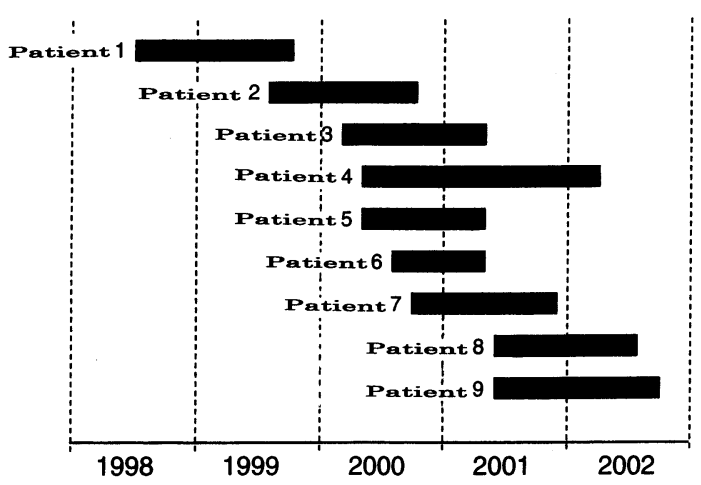

Fig. 2 Nine patients receiving long-term platelet transfusion and its duration.
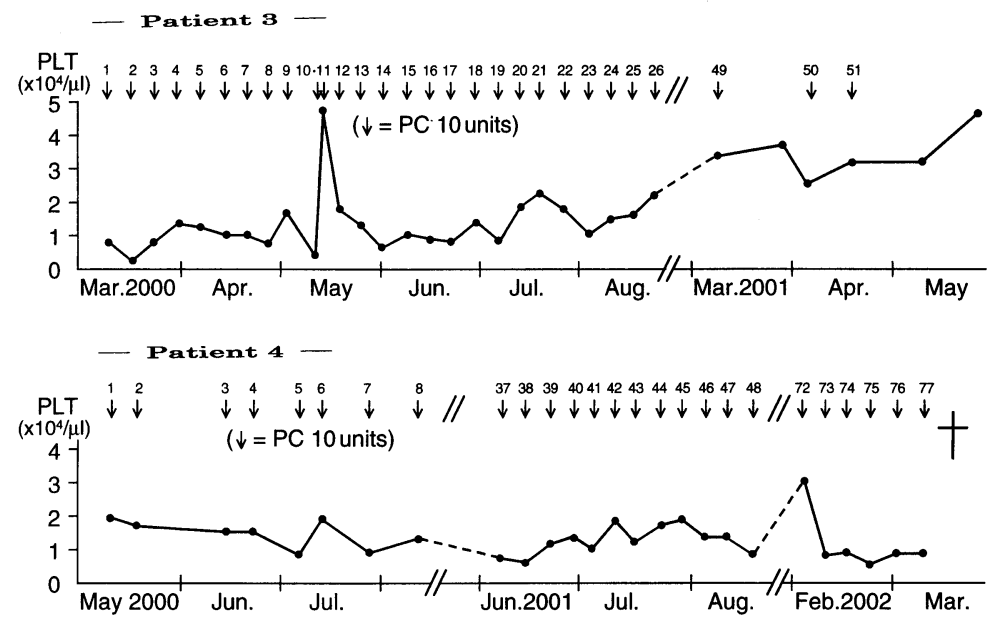

Fig. 3 Practice of long-term platelet transfusion at an outpatient clinic in patient 3 and patient 4 . 


\section{考察}

われわれの病院では最近になって外来血小板輸 血が激増したが，それは血小板輸血を受ける患者 の数が大幅に増加したためではなく患者の輸血回 数が増加したこと, 或いは頻回輸血患者（全て血 液疾患患者) が増加したことが原因であった (Fig. $1,2)$.

9 例の長期継続例の基礎疾患は AML と MDS であるがその腫瘍としての活動性は低く造血障害 が主な病態であった．そのことが血小板輸血を続 けながら長期間外来通院が可能であった大きな要 因と考えられる。一般的には血小板の寿命からこ の様な患者には 2〜3 日に一回の頻度で血小板を 輸血することが推奨されている3 ${ }^{344}$. しかしわれわ れは患者の負担を考慮し, 患者の出血傾向に応じ て微調整しながら 1〜4 週間隔で血小板輸血を繰 り返した。歯肉出血中のCase 3 において PC10 単位輸血後翌日の血小板数が有意に増加しており (Fig. 3)，PC10 単位の 1 週間隔での継続輸血が出 血予防にかなり有効であることが示唆された．更 に最終的に出血死した患者は 9 例中 1 例のみで あったことも (Table 1)，この方法の有用性を示し ている.もしこれらの患者が一切血小板輸血を受 けなかったらどうなったかを想像すると，より早 期にもっと多くの患者が出血死したと思われる. Sagmeister らは重症再生不良性筫血患者の出血 予防に外来で長期に亘って血小板輸血を行い, $78 \%$ の患者で輸血間隔を 1 週以上（その内 3 週以 上が7\%)空けたがなんら安全性に問題はない，と 報告している5 ，今回のわれわれの検討は非寛解 の AML 例でも病気の活動性が低い患者なら同様
の方法で出血傾向を管理できることを示した.

外来血小板輸血の長期継続例の多くは予後不良 であったが一部の患者は良好な転帰を取った。そ の様な症例にとっては血小板輸血を繰り返しなが ら危機的状況を乗り切ったことは臨床上極めて有 意義であったと言える．残念ながら死亡した患者 も闘病期間の大部分を在宅で過ごし，長期の入院 生活に比べると QOL は良好であった，その家族 にとっても患者と共に自宅で過ごした日々はかけ がえの無い貴重なものであったと思われる．従っ て予後不良例においても外来血小板輸血は在宅を 可能にする重要な治療手段である．継続的に血小 板輸血が必要な血液疾患患者とその家族のため に，われわれは血液センター・病院輸血部・診療 科の連携を密にして外来血小板輸血をより精力的 かつ効率的に推進していく必要がある。

\section{文献}

1）池田康夫, 半田 誠, 平野武道：血小板輸血の適 応一慶応義塾大学病院での濃厚血小板の使用の 実態調查加一。 日輸血会誌, $36 ： 780-783,1990$.

2）面川進，能登谷武，吉岡尚文，三浦 亮：当院 における血小板輸血の現状一特に最近 2 年間の 血液製剂構成の変化を中心に。日輸血会誌，40： $599-605,1994$.

3）浅井隆善：疾患・病態別の輸血療法 5) 白血病 6）再生不良性貧血（日本輸血学会認定医制度指定 カリキュラム), 86 - 89 .

4）品田章二：成分輸血：適応と実際 2. 血小板輸 血の適応と実際. 日内会誌， $85 ： 806-810,1996$.

5) Sagmeister, M., Oec, L., Gmur, J. : A restrictive platelet transfusion policy allowing long-term support of outpatients with severe aplastic anemia. Blood, 93 : 3124-3126, 1999. 